ks. Grzegorz Barth

Katolicki Uniwersytet Lubelski

\title{
Karl Barth's doctrine about Menschlichkeit Gottes. Theological and hermeneutical implications
}

\section{NAUKA KARLA BARTHA NA TEMAT MENSCHLICHKEIT GOTTES. IMPLIKACJE TEOLOGICZNE I HERMENEUTYCZNE}

Nauka Karla Bartha na temat Menschlichkeit Gottes („Człowieczeństwo Boga”) uchodzi za wizytówkę twórczości wielkiego bazylejczyka, która implikuje ważne treści i aspekty teologiczne oraz hermeneutyczne. Koncepcję tę szwajcarski teolog opiera na regule metodologicznej, determinującej specyficzne rozumienie Boskiego samoobjawienia się, które ma rozjaśnić i zinterpretować każdą postać chrześcijańskiej doktryny w świetle tego, co zostało poznane w Jezusie Chrystusie. Zgodnie z regułą, potwierdzającą kierunkowość i powszechność chrystologicznego myślenia, Barth podejmuje wysiłek opisania za pomocą tzw. "doktryny łaskawego wyboru" (doctrine of gracious election) preegzystencję Jezusa Chrystusa, aby pokazać, że Bóg „od początku” jest ukierunkowany na człowieka; jest jego odwiecznym „Miłośnikiem". Z nauki o Menschlichkeit Gottes, której sedno stanowi relacja Boga wobec ludzi, wyrażająca Jego łaskawość, wynikają liczne implikacje teologiczne i hermeneutyczne.

Słowa klucze: Karl Barth, Menschlichkeit Gottes, teologia, hermeneutyka, Zbawienie, uczłowieczenie.

The original theological (and hermeneutical) project is hidden under the cover of such formulated theme, which creator is Karl Barth, one of the most outstanding representatives of Reformed theology. It is 
a kind of showcase of his work, namely Menschlichkeit Gottes study, which implies important content and aspects of theological and hermeneutical for contemporary thinking.

\section{Methodological rule of Barth's theology}

"The humanity of God - says Barth - certainly would mean: God's relationship and his generosity for man: God, who speaks to him in the promise and commandment: God's existence, ascent and action for him: a community that God sustains with people: free grace of God, in which $[\mathrm{He}]$ is not anyone else, because when God wants to be man's God, he really is".

His teaching on Menschlichkeit Gottes the Swiss theologian based on methodological rule, which implies a specific understanding of God's self-revelation, embracing reflection on any other "subject" of the doctrine and try to interpret in the light of what has been learned in Jesus Christ. To better understand this postulate of "christologicalness" Barth takes into account and tries to think through a number of properties (Trinität, Offenbarung, Ereignis, Verberung) in the horizon of the hidden mystery of God. The theologian from Basel, rejecting apophatic approach that invalidates "meaningful content" in speaking about God, insists on the vision of God as - remaining in an absolutely unique relationship to the people and to the world - the Secret. God, being incomprehensible mystery covers himself (Verberung), and also discovers himself to man (Entbergung) and manifests. Concealment (Verstellung) is inseparable from the nature of the truth itself (aletheia). Christ's humanity no less conceals the divinity of God than is able to reveal it by human eyes ${ }^{2}$. Nevertheless, Jesus Christ, the eternal Word of God, is, according to Barth - "knowability of God" (die Erkennbarkeit Gottes) ${ }^{3}$. Continuing his reflections on the understanding of the divinity of God, the Swiss theologian emphasizes that divinity is revealed not so much in the empty space of the divine being-for-itself (Fürsichseins), which in the most authentic existence as a Partner of a man who speaks to him and co-works with him. The way of God's self-revelation corresponds to the very nature of God as a living creature and fully free. Three issues are of fundamental importance for Barth: 1) inseparability of formal and substantive aspect of the event

$1 \quad$ K. Barth, Die Menschlichkeit Gottes, ,Theologische Studien. Eine Schriftenreihe“, Heft 48, Zürich 1956, p. 3.

2 Ibid.

3 Cf. Church Dogmatics, II/1, (Edinburgh 1956-75). 
of divine revelation, 2) everything that God does and how he does, is the fruit of his freedom, which is his true divinity (Divinität), 3) what is significant for Barth's doctrine - divinity as such is the nature of what is human (Humanität) ${ }^{4}$. Theologian depends on exposure of God's sovereignty (freedom) in its self-establishing through its self-describing, limited and orderly coexistence with people. It is essentially an event which really made our knowledge. This event is the dynamic center of theology, which having its own ratio surrenders whole Christian existence to its norm.

According to the methodological rule confirming the directivity and the universality of Christological thinking, Barth makes an effort to describe with the so-called "doctrine of gracious election" pre-existence of Jesus Christ. It shows that God "from the beginning" is directed at the man. Election is God's self-choice, God's decision to be God in that sense in which and to the man Jesus. The consequence of this approach is that God is the one who decides about being in relation to us by Jesus Christ ${ }^{5}$. If this is God's election, which is the essence of God, we cannot then argue about the second person of the Trinity, it is the Logos asarkos. We cannot talk about Logos asarkos as someone abstract, who is eternally self-existent, without any need of reference it being a pro nobis. For Barth, the whole divine Essence cannot be determined on a different basis, but on the perception of his presence and acting as the Incarnate Word. Therefore theologian speaks of the Logos incarnandus, who is determined in his being the "eternal divine decision against incarnation in time" . The unique contribution of Barth in the doctrine of election lies in the fact that Jesus Christ is not only "the subject of elections" (object of election), but that he is also "object of election", and as such he is not an abstract Logos asarkos but he was, is and always will be Jesus Christ, God-Man.

The relationship between divinum and humanum explains about reality mutually maintained relationship where there is the most complete opening and exchange. This is achieved in the Person, because Jesus Christ is true God of man (Gott des Menschen) and true Man of God (Mensch Gottes). In looking at Jesus Christ there is something definite, however, the divinity of God does not exclude his own humanity,

$4 \quad$ Cf. Die Menschlichkeit Gottes, p. 10.

5 J. Webster, Introduction to God's Being Is in Becoming: The Trinitarian Being of God in the Theology of Karl Barth, Eerdmans, 2001, p. 17.

6 Cf. B. L. McCormack, Grace and Being: The Role of God's Gracious Election in Karl Barth's Theological Ontology, [in:] The Cambridge Companion to Karl Barth, J. Webster(ed.), Cambridge 2000, p. 94; See: M. O'Neil, Karl Barth's Doctrine of Election, EQ 76(2004), p. 311-326. 
but includes it in itself. Therefore, Barth reports the need to undertake actions aimed at further insights and findings on how divinity (divinum) and humanity (humanum) contain in each other.

In and through this relationship, it can be brighten up what is the Hermeneutyka most important for people and their history, and what was more or less consciously considered as ordinary, having lost its meaning. Trying to recover these forgotten areas is a hermeneutic penetration into the essence of our humanity, which is ultimately the humanity of God.

\section{Humanization as salvation - salvation as humanization}

In view of the fact that in the aforementioned sense: God is human, it results - according to Barth - quite specific promotion of human (Auszeichnung des Menschen): every creature that has a human face with the entire inventory of their skills and capabilities that are partially common with other creatures and partially different from them ${ }^{7}$. With the same human nature also strange, crazy and desperate, you should see in it something unique and specific. Given the above assumption, you need to accept the idea that the basis of free decision ("gracious choice") of God is Jesus Christ, who is for us to be a Brother and God being a Father ${ }^{8}$. Underlying the decision of God, who humanizes himself is a real desire for the salvation of man, which should be accepted by him. From the perspective of the recipient of God's decisions - as noted by Barth - humanization does not mean, however, that the sinful fall of man is "extinguished", and his well-being will be able to minimize it. Humanization - says theologian - is a true and real salvation! In the literalness of this statement the Swiss theologian presupposes a clear opposition to any illusory interpretations of the work of salvation accomplished by God, as well as attempts to bring it to a form of human self-redemption. Salvation - continues the theologian - is given to man as a free act of God that brings him real recapitulatio, recreatio and deificatio as humanisatio.

In Jesus Christ, and specifically in his omnipotentia oboedientialis - as it was defined by a traditional theology - the man is irrevocably launched into space of large (almost unlimited) opportunities as a way of realizing a sovereign divine freedom. Salvation as humanization, then, is nothing more than a "metaphysics of possible", based on God's offered promise that reliably brings Christ. A man can become this what he himself could never become or be. Being condemned to his

Menschlichkeit Gottes, p. 16.

Ibidem. 
human possibilities, he can surpass each other towards the otherness of God - this creative diversity, thanks to which impossible henceforth is considered as possible.

\section{Culture and practicing theology}

The second implication associated with the teaching of Menschlichkeit Gottes concerns - according to Barth - theological culture (pre- and post-Kantian philosophy, classical philosphy, socialism and theoretical and practical nuclear physics), whose object (die Sache) is determined as a whole by the humanity of God. Starting from Barth's axiom that God in his divinity is human, it cannot be dealt with God (in se) or man (in se), but always a man meeting God and God meeting man: their mutual intercourse and a common history in which this community becomes an event aimed towards the upcoming (adventus) goal. According to this famous resident of Basel there is a need of mental return (Verkehr): what is divine (as defined theologically) in the direction of the man, leading to the return of the human (anthropology, culture) towards God in order to be able to see, understand, try to speak the Word, as well as the grace of God, which constantly cry and arouse human gratitude (eucharistein). Divinity and humanity of God in Jesus are united in a particular sequence of diversity and unity. So when we stick to this basic axiom, then there the modest figure of that good appears which is cultivated theology (kultivierte Theologie) ${ }^{9}$. Culture and theology need each other in order to better speak what they have to communicate to man. In the spirit of Barth's paradigm the task of theology as a field of interpreting and interdisciplinary becomes clearer. Its case is an attempt to lighten the ontological tension in human existence (theology as a modus experiendi). In the light of Revelation it wants to explain hermeneutic construction of the world lived and articulated in the form of language. In this way they endorse a new way to learn about theology, and also explains the existence of man in the world around him. Starting from the Word mediated (historically, linguistically, symbolically, by cultural artifacts) comes to words, to sense and reflection, making a continuous exegesis of all the meanings that appear in the world and culture, as well as negotiating their ideological distortion ${ }^{10}$.

$9 \quad$ Cf. Die Menschlichkeit Gottes, p. 19.

10 P. Ricoeur, Egzystencja i hermeneutyka [Egzistence and hermeneutics], K. Tarnowski, [in:] S. Cichowicz (ed.), Egzystencjai hermeneutyka. Rozprawyo metodzie [Egzistence and hermeneutics. Dissertation about the method], Warszawa 1975, p. 146 . 
Of course, in this approach prospect relations of the subject to an objective basis, and therefore a situation in which the subjective element is eliminated to achieve the highest possible objectivity, they are relativized by the basic recognition of hermeneutical reference to the Hermeneutyka subject. In this way the impact of the traditional relationship between subject and object - in which the subject interrogates the subject, and if it is the champion, it gets an answer from him - has been significantly reversed. Now the object - which henceforth should be called the subject of matter - puts the entity in question. This is true not only at the formal level, in interrogating whether he understands himself correctly, but also at the material level, in interrogating whether the response of the text enlightens $i^{11}$. In this context, the debate between Barth and Adolf von Harnack is noteworthy. For Harnack, it was obvious that the purpose of theology is to "determine the content of the gospel," that is "to gain intellectual control over the object"12. Barth answers that the scientific nature of theology is a commitment to the mind that its object is primarily subject (ultimately the Holy Spirit), which has to become the subject again ${ }^{13}$. This is what emerges here is the memory that God is not a phenomenon which is at the disposal of the scientific inquisitiveness, as the other phenomena are available in the world. Barth establishes a category of revelation in opposition to the scientific, as we know it today, and so in relation to imperiousness of objectum and normative method widespread today. Perhaps Barth felt perfectly this insight when he refused to be defined by the protest of the spirit of the present time, which must probably first learn to understand itself ${ }^{14}$.

\section{Theology as an attitude of the understanding faith}

The third implication for the teaching about Menschlichkeit Gottes demands from us a certain attitude (Haltung) and equilibrium (Ausrichtung) between the Christian and theological thinking and the way of its expression. In theology - notes Barth - we are not dealing with a "subject" in an empty space or bare theory. He states that tkeheology should not describe the truths remaining at rest, or even those restless,

11 Cf. J. M. Robinson, Hermeneutics Since Barth, [in:] J. M. Robinson, J. B. Cobb (ed.), The New Hermeneutic, New York, Evanston, London 1964, p. 24. und Antworten: Gesammelte Vorträge, vol. 3, Zollikon-Zürich 1957, p. 8.

Cf. ibidem, p.10.

14

Cf. ibidem, p.19. 
conceived and coming down to the language, being an abstract truth about God. It can never monologically ascertain, reflect and refer. Divine humanity creates in this respect completely new opportunity because it is an event (Geschehen) rather than pictorial fixation. So Barth emphatically points out that the main form of theology exists in connection with the prayer and the preaching of the Word (kerygma). Consequently, it can only be dialogic ${ }^{15}$. Theology must be accompanied by awareness of the inseparability of form and content in the discourse. Any attempt to conceptualize the center of theology will try to control the object of theology. Barth is fully aware that the actualistic center of his theology has its own ratio, from which a system can be only developed.

Theology as a modus experiendi demands a certain attitude. The essence of understanding involvement in theology should not be established (a propri) without any reference to the theological topic (die Sache), but on the basis of reflection on its specific nature. What will or will not be understood, it becomes apparent only in the process of understanding each other, so it is not needed to lay down any prior rules at this point. Even if the issue of understanding is realized in three aspects: a) comprehension, b) understanding of the "subject of matter", which is coming to an expression in the text, c) intelligibility of modern testimony is held by the "object", understanding that commitment ultimately is something one ${ }^{16}$.

This attitude carries decisive and existential momentous attitude, an example of which we have in the St. Paul's letters. In the phenomenological interpretation of the Letter to the Galatians, Heidegger notes that Paul's explication of the Christian experience of life has its foundation in the sense of life itself, where theoretical things are relegated to the sidelines. The Apostle "achieves explicatory system, which presents itself as a theoretical explication. It is about a return to the source of experience and understanding of religious explication"17. It's all about awareness of faith, upon which the explicationis is based. An expression of logi,sasqai becomes typical for the articulation of the awareness of faith which allows a particular person to understand

\footnotetext{
$15 \quad$ Cf. ibidem, Die Menschlichkeit Gottes, p. 20.

16 Cf. H. Ott, What Is Systematic Theology? [in:] The Later Heidegger and Theology, J. M. Robinson, J. B. Cobb (ed.), New York 1963, p. 79.

17 Cf. M. Heidegger, Fenomenologia życia religijnego [Phenomenology of religious life], G. Sowiński, Kraków 2002, p. 68.
} 
the attitude of faith ${ }^{18}$. Heidegger warns against an attempt to extract individual terms (faith, justice, flesh) in order to construct their meanings of many passages of Paul's writings. He says that the idea of his theological system is also misguided. It should be highlighted the Hermeneutyka basic religious experience and staying in the horizon of this experience, trying to understand the relationship that exists between it and any source religious phenomena. The religiosity of early Christianity - says Heidegger - is contained in his actual life experience and it is. Moreover, the life experience is historical, therefore this religiosity lives temporality. Central phenomenon revealing a direct reference of Paul's life is - in the opinion of Heidegger - preaching. It is subordinated to the "how" of preaching, which is epistolary. This analysis needs to emerge from the Paul's situation - from the motivation of epistolary communication. It is the situation of his religious passion, the fight that takes place between "law" and "faith" as two distinct attitudes and ways of salvation.

There is here a twofold movement, consisting in the unity of belief, and then explaining the beliefs in thinking. The first relates to the fact that theology should adapt itself to the basic situation that faith is one and indivisible, and therefore also its subject is one and indivisible. It appears that in the case of Barth's theology this assumption, especially in its eschatology or unitary charitology is symptomatic. The second element of the earlier statement addresses the problem of a "thinking belief". It is about the fact that theological act of reflection is the specific mode of belief. The fact that an act of theological reflection is an act of belief, movement of the same faith, it does not mean that only believers can understand the theological thinking. For the "subject

18 This general phrase captures the sense of the ministry of St. Paul, who says: ouv coti i'kanoi, ev smenavfV e'autwhlogi,sasqai, ti w'jev xe'autwhav IIV h' i'kano,thj h'mw hev k tou /qeou /(2 Cor 3:5). It does not mean that the Apostle is a thinker, but it is explained in the broad sense. The expression I o gi , s a s qa i means: 1. matter: a) judging, taking into account (Rom 4: 8; 1 Cor 13:5) b) evaluation, assessment, treatment (Acts 19:27); 2. thinking (about), meditation, focus one's mind (John 11, 50, Heb 11, 19), right to take plans (1 Cor 13: 11); 3. to think, believe, opine (Rom 2: 3; Phil 3, 13). This general expression gives meaning to the ministry of St. Paul, who has in mind a whole existential reflection within the structure of its activity Apostolic: reflection, judging, planning, solving. The intention of Paul is not purely logical act divorced from deeds. There is always thinking originates in deeds. Only God allows Apostle advent of proper judgment. Cf. Theological Dictionary of the New Testament, G. Kittel (ed.), trans. G. W. Bromiley, Vol. 4, Michigan 1995, p. 288. 
matter" of faith and theology, Christ is understandable, he is designed for the process of understanding to communicate with him ${ }^{19}$.

Theology is a movement of faith, where faith is growing the understanding that this is essentially the same clarity of thought. Faith is trying to seek this clarity, from which it is directed toward preaching, communication and achieves a common understanding. Theology is realized in this sense as an unfolding of the structures of meaning of the one and indivisible meaning-content understood in believing" 20 .

Uniting the divine and human nature in Verbum, Christ overcame the inadequacy(imperfect) of human expression of God. As an event, Logos is not a-temporal spirit, but still updated and renewable word from the act of understanding. The word (verbum exercitus) is not formed and shaped in thinking (verbum interius) ${ }^{21}$. This word is directed towards the thing (die Sache $)^{22}$, but it cannot embrace it together as a whole, so the thinking goes into constantly new ideas and basically in none of them is fulfilled completely. The identity of the thinking of its linguistic manifestation, proves that the meaning of words cannot be separated from the process of the preaching ${ }^{23}$. Therefore, any attempt to reconstruct the speech, simplification of it without thinking about the thing which language speaks, must be regarded as irrelevant. Thanks to the teaching of Menschlichkeit Gottes theology is able to discover its own potential - as J.-L. Marion says currently only theology can provide the intellectual fun, because it can jump between small and big words. Its greatness lies between an act of trust and suspicion, trust in revealing and giving God as stored and unconditioned act of God, and criticism of its acceptance by the man's faith in the intricacies of its existence.

$19 \quad$ H. Ott, What Is Systematic Theology?, p. 90-92.

$20 \quad$ Ibidem, p. 94.

21 See M. Oliva, Das innere Verbum in Gadamers Hermeneutik, "Hermeneutische Untersuchungen zur Theologie", Tübingen 2009; A. Wiercinski, The hermeneutic retrieval of a theological insight: verbum interius, [in:] Between the Human and the Divine: Philosophical and Theological Hermeneutics, (ed). A. Wierciński, “The Hermeneutic Press", Toronto 2002, p. 12;

22 "Articulus fidei est perceptio divine veritatis tendens in ipsam" ("perception of the truth of God, striving to itself"). S. Th., II-II q.1, a. 6.

23 Cf.H.-G. Gadamer, Prawda imetoda.Zaryshermeneutykifilozoficznej[The Truth and Method. The outline philosophical hermeneutics], translated by B. Baran, Warszawa 2007, p. 576. 


\section{God's saving humanism}

The fourth implication of reflection on the humanity of God refers to the sense and tone of our words, which should be creative and posiHermeneutyka tive. The main theological task - as noted theologian - is the proclamation of God's covenant with man and an indication of the place where it was given to a man once and for all the data. It confirms the truth about man - the constant rebel, denouncing "no" to whom God remains faithful love and does not turn away from him. Theology in the context of addressed issues must take the word "no" that Jesus Christ took upon himself to protect us from further nagging and bullying. While every "no" close man within himself, an ongoing God's humanity makes affirmation (Bejahung) of man. Necessary becomes competent constellation of our words that would express God's saving humanism - his solidarity with man $^{24}$. Barth wants to say that the most existentially important issues, and this is the work of salvation is binding regardless of time and place - is still renewable in the Holy Spirit response to questions asked by man. This intuition should be developed in relation to Barth's Römerbrief. In the preface to the first edition, the Swiss theologian in a few deft brush strokes outlined the direction of his hermeneutics, which is a part of the saving humanism. He stressed the importance of our view throungh the "historical" on the spirit of the Bible, which is the eternal Spirit. What was "seriously" remains "seriously", which today is "seriously" and is not merely incidental and peripheral, it is in a direct relation to what was "serious". Our questions if we understood correctly ourselves, are Paul's questions, and his answers; if their light enlightens us, they have to be our answers. Understanding history is continuous, more and more open and urgent discussion between yesterday wisdom and today wisdom, which are the same ${ }^{25}$. Römerbrief and Barth's declaration exploded in the void left by the disappearance of hermeneutics ${ }^{26}$. It is not a hermeneutic position, theory of interpretation, but a kind of hermēnei action, which is rich in its suggestive interpretation of interconnectedness of language, translation and exegesis ${ }^{27}$. This is an interpretation in which

$24 \quad$ Cf. Die Menschlichkeit Gottes, p. 23.

25 Cf. Idem, Der Römerbrief, [Einleitung], Zollikon-Zürich 1947.

26 Gadamer declares that Barth's work was ,a hermeneutical manifesto”. Cf. H.-G. Gadamer, Hermeneutik und Historismus, „Philosophische Rundschau” 9 (1962), p. 246.

$27 \quad$ Synonymy of hermeneia with exegesis has been replaced by the distinction in terminology: theory and practice. However, exegetical theology and exegesis and the word exégeisthai can be treated as synonyms of hermèneuein and 
the matter of Paul's language is translated and proclaimed anew in the language of our "today".

Theology finds its position in the middle of an arc extending between the text and the contemporary preaching. It is located "between" exegesis, which mainly focuses on the text as such and a practical reflection, which in turn focuses on church preaching. The discussion on its nature must be supported by the word "between" present in mind. This means constantly staying in the belief that we are dealing with "between" inside continuation. Theology as a "doctrine", amounting outside the "hermeneutic arc", insulated on the one hand from the exegesis and on the other from the preaching, it immediately becomes understanding without foundation. It must therefore be assumed that natural theology is hermeneutic. Hence the discussion of theology will be able to show its legitimacy if it can demonstrate the extent to which its specific function is essential to the hermeneutical transfer, which moves trans-lating of meanings. It is a translation engaging in understanding when it is perceived as a movement, encouraging us to take up theology ${ }^{28}$.

In this context, attention should be paid to hermeneutic concept of David Tracy, who proposes conversation-correlation model of systematic theology. He says that generally accepted task of theology is reduced to "establish a mutually critical correlation between the reading of the Christian tradition and contemporary interpretation of the situation" 29 . Tracy acquires and develops distinction between S. Ogden on the criteria of suitability appropriateness with respect to the tradition and the criteria of intelligibility in relation to the situation. The first criteria are taken from the apostolic testimony that determines the meaning and identity of Christianity, the other provide a criterion of the truth of Christian faith. The criteria of appropriateness are conceived as key to assessing any subsequent theological statements in expressions of that suitability for apostolic testimony expressed normatively in the Scripture (norma normans sed not normata $)^{30}$. By contrast, the criteria of intelligibility concern the

hermeneutica, and indeed can be used in a similar sense to theologia hermeneutica and exegetic. G. Ebeling, Hermeneutik, [in:] Die Religion in Geschichte und Gegenwart, Vol. $31959^{3}$, p. 243.

M. Heidegger, Fenomenologia życia religijnego [Fenomenology of religious life], p. 81-82.

Cf. R. M. Grant, D. Tracy, A Short History of the Interpretation of the Bible, Philadelphia 1984, p. 170

Ibidem, p. 176. 
"relative adequacy" in relation to the contemporary experiences and situations. It is important that these criteria allow for the unveiling of the classic events and transformatively affecting the situation. Using the hermeneutical theory of Gadamer and Ricoeur, Tracy researches Hermeneutyka the nature of Christian classics ${ }^{31}$. Additionally, he defines systematic theology mainly as a hermeneutical proposing that its task was to recover the claims of interpretation and the truth of the Christian classics. According to Tracy, classics are those texts (actually the events, people, images, rituals, symbols referring to the text), which on the one hand, contain an excess and continuity of meaning, and on the other hand constantly rely on the final interpretation. They are an example of radical constancy passing into the durability and radical impermanence in excess of the importance of passing through the constantly changing reception. In this way they exist in different forms, but actually reveal "permanent possibilities of meaning and truth." Classic is an unmatched exemplification of human understanding of the truth revealed through his effective nature affects our horizons of understanding and concretes our self-understandingni ${ }^{32}$. Appreciating the impact of the historical-critical method and literary-critical for theological exegesis, which could see pluralism and underdetermination of own traditions, D. Tracy conceives the idea of hermeneutical theology, emphasizing its ability to combine conciliatory methods, interpretation, and the personal commitment of the theologian - his intelligence, and imagination. Such a theology has to serve the practice of reflecting life ${ }^{33}$. The correlation method, proposed by American theologian - according F. Schüssler Fiorenza - is based on a distinction between language and reality expressed in the language. Such a distinction, however, seems to downplay the historicity of language and culture, mistakenly assuming that the various forms of expression of cultural categories and the language may change when the reality expressed in them and through them remains the same. In addition, the correlation method emphasizes continuity and identity, but not sufficiently take into account the variability and non-identity in the development of faith and theology. It formalises the tradition of bringing it to an

31 Cf. D. Tracy, Plurality and Ambiguity: Hermeneutics, Religion, Hope, New York 1987.

32 Cf. F. Schüssler Fiorenza, Systematic Theology: Task and Methods, http://store. fortresspress.com/media/downloads/0800662911Chapter1.pdf, p. 33.

33 Cf. D. Tracy, Talking About Gog: Doing Theology in the Context of Modern Pluralism, New York 1983, p. 72. 
abstract formula ${ }^{34}$. Recognizing the weaknesses in the approach of the grater, Schüssler Fiorenza proposes a vision of theology, which applies the so-called wide reflective equilibrium, the implementation of which involves four tasks: 1 . reconstructive interpretation of tradition, 2. consideration of relevant theory constituing its background, 3. assessment of the ongoing current (Christian) experience, 4. taking into account the different communities of discourse. Each of these mentioned elements is not isolated, but there is a close connection with the other ${ }^{35}$. In the hermeneutical solutions presented above, which are developed intuition of K. Barth - especially included in his teachings about Menschlichkeit Gottes - dominates the clear conviction about the need for mutual correlation between interpretations of tradition and the current situation, the theological correlations which includes the application and the response.

Key words: Karl Barth, Menschlichkeit Gottes, theology, hermeneutics, salvation, humanization.

\section{Bibliography:}

1. Barth K., Der Römerbrief, [Einleitung], Zollikon-Zürich 1947.

2. Barth K., Die Menschlichkeit Gottes, „Theologische Studien. Eine Schriftenreihe“, Heft 48, Zürich 1956.

3. Barth K., Ein Briefwechsel mit Adolf von Harnack, [in:] K. Barth, Theologische Fragen und Antworten: Gesammelte Vorträge, vol. 3, Zollikon-Zürich 1957.

4. Ebeling G., Hermeneutik, [in:] Die Religion in Geschichte und Gegenwart, Vol. $31959^{3}$.

5. Gadamer H.-G., Hermeneutik und Historismus, „Philosophische Rundschau" 9 (1962).

6. Gadamer H.-G., Prawda i metoda. Zarys hermeneutyki filozoficznej [The Truth and Method. The outline philosophical hermeneutics], translated by B. Baran, Warszawa 2007.

7. Grant R. M., Tracy D., A Short History of the Interpretation of the Bible, Philadelphia 1984.

8. Heidegger M., Fenomenologia życia religijnego [Phenomenology of religious life], G. Sowiński, Kraków 2002.

9. McCormack B. L., Grace and Being: The Role of God's Gracious Election in Karl Barth's Theological Ontology, [in:] J. Webster (ed.), The Cambridge Companion to Karl Barth, Cambridge 2000.

34 Cf. F. Schüssler Fiorenza, Systematic Theology: Task and Methods, p. 46-47.

35 Idem, Systematic Theology and Hermeneutics, [in:] A. Wiercinski (ed.), Between the Human and the Divine: Philosophical and Theological Hermeneutics,. Toronto 2002 , p. 511. 
10. O’Neil M., Karl Barth's Doctrine of Election, EQ 76(2004).

11. Oliva M., Das innere Verbum in Gadamers Hermeneutik, "Hermeneutische Untersuchungen zur Theologie", Tübingen 2009.

12. Ott H., What Is Systematic Theology? [in:] J. M. Robinson, J. B. Cobb (ed.), The Later Heidegger and Theology, New York 1963.

13. Ricoeur P., Egzystencja i hermeneutyka [Egzistence and hermeneutics], [in:] S. Cichowicz (ed.), K. Tarnowski, Egzystencja i hermeneutyka. Rozprawy o metodzie [Egzistence and hermeneutics. Dissertation about the method], Warszawa 1975.

14. Robinson J. M., Hermeneutics Since Barth, [in:] J. M. Robinson, J. B. Cobb (ed.), The New Hermeneutic, New York, Evanston, London 1964.

15. Schüssler Fiorenza F., Systematic Theology and Hermeneutics, [in:] A. Wiercinski (ed.), Between the Human and the Divine: Philosophical and Theological Hermeneutics, Toronto 2002.

16. Schüssler Fiorenza F., Systematic Theology: Task and Methods, http://store. fortresspress.com/media/downloads/0800662911Chapter1.pdf.

17. Theological Dictionary of the New Testament, G. Kittel (ed.), trans. G. W. Bromiley, Vol. 4, Michigan, 1995.

18. Tracy D., Plurality and Ambiguity: Hermeneutics, Religion, Hope, New York 1987.

19. Tracy D., Talking About Gog: Doing Theology in the Context of Modern Pluralism, New York 1983.

20. Webster J., God's Being Is in Becoming: The Trinitarian Being of God in the Theology of Karl Barth, Eerdmans, 2001.

21. Wiercinski A., The hermeneutic retrieval of a theological insight: verbum interius, [in:] A. Wiercinski (ed.),Between the Human and the Divine: Philosophical and Theological Hermeneutics, "The Hermeneutic Press", Toronto 2002. 